\title{
Innovations of Food Security in Central, Eastern and Western Europe (Review)
}

L. Nardelli (Lauren Nardelli), D.J. West, Jr. (Daniel J. West, Jr.)

University of Scranton, PA, U.S., Master of Health Administration

Graduate Program, USA

\section{E-mail address:}

lauren.nardelli@scranton.edu

\section{Reprint address:}

Lauren Nardelli

University of Scranton, PA

Scranton Hall

Scranton, PA 18510

USA

Source: Clinical Social Work and Health Intervention

\section{Reviewers:}

Vlastimil Kozon

Allgemeines Krankenhaus - Medizinischer Universitätscampus, Vienna, Austria

Roberto Cauda

University Catholica Clinica, Gemeli, Rome, Italia

\section{Key words:}

Food Security. Europe. Impact. Prevalence. Slovakia.

\section{Publisher:}

International Society of Applied Preventive Medicine i-gap

CSWHI 2019; 10(1): 35 - 38; DOI 10.22359/cswhi_10_1_05 @ 2019 Clinical Social Work and Health Intervention

\section{Abstract:}

Objective: This research will attempt to identify the causes for the increase in the inefficiencies of nutrition. Additionally, there is an effort to identify what is missing nutritionally by means of conducting a comparative analysis against surrounding European countries to help determine these insufficiencies.

Methods: This paper is a secondary resource on the access, availability, affordability, and education on Food Security. 
Results: Surrounding countries of Central, Eastern and Western Europe should change their current policies and implement certain laws for food wasting. These countries should increase efforts to further investigate diseases that are attributed to severe food insecurity.

Conclusion: This research noted that surrounding countries in Central, Eastern and Western Europe are implementing food programs and agriculture policy changes.

\section{Introduction}

Food insecurity is a limited access to nutritious food necessary to live a healthy lifestyle. Food insecurity does not affect all individuals. Individuals who are food insecure have social patterns of vulnerability in the household and environment. It is a significant public health problem affecting mostly the middle to low income class in various countries. Individuals who are food insecure are more susceptible to chronic diseases due to the inability to access adequate health resources.

Food security was first defined by experts in the $20^{\text {th }}$ century as the ability of a country to provide its residents enough nutritious food necessary for individual's health and to lead productive lives (Dzurickova, 2). However, in 1996, at the World Summit on Food Security, the Food and Agriculture Organization (FAO) stated food security exists when at all times, people have physical, social, and economic access to sufficient, safe, and nutritious food to meet needs and preferences for an active healthy lifestyle (Dzurickova, 2). This term has expanded vastly since continuing research in the subject matter.

\section{Concerns}

Malnutrition continues to be a single threat to public health globally. It contributes to 2.2 million child deaths per year and in Europe, it is estimated 33 million people are at risk for malnutrition (eufic, 2011). When a child faces nutritional deficiencies she or he is not getting the proper nutrients needed for child growth and development which can lead to stunted growth in children.

Food wasting is another major factor in food security. According to ec.europa.edu, (2017), in Europe it is estimated that 20\% of the total food produced is lost or wasted. Food waste does not only happen in supermarkets but is lost along the whole supply chain from farms to processing and manufacturing. Climate change can also contributed to food waste.

Obesity rates are currently on the rise worldwide. Even though people suffer from lack of calories and nutrients, the number of individuals who are overweight and obese is often associated with low income. Lower income individuals turn to processed or fast food because it is affordable and accessible. Behaviors and excess consumption of food can increase personal health burdens and chronic diseases such as diabetes, heart disease and cancer (easac.eu, 2017). When individuals are not intaking the proper nutrients needed to help the body fight chronic diseases, it makes them more susceptible to chronic diseases that can be detrimental to their health.

\section{Prevalence and Impact}

According to the European Pediatric Association (2017), the prevalence of food insecurity has increased during recent years in several European countries. The United 
Nations Children's fund conducted a study that found within 28 European countries $18 \%$ of households were moderate to severe food insecure; $14 \%$ had the inability to access food; $20 \%$ of households reported having lack of funds to purchase food (European Pediatric Association, 2017).

\section{Impact}

Access is one of the many contributing factors that impacts food insecurity. When individuals do not have a car to get to the grocery store or the closest grocery store is over 100 kilometers away, this reduced access to food in the household.

The demographic transformation is making it hard to keep up with food demand due to population growth. People are constantly migrating from place to place with growing families. This can be seen in the rural aging population because elderly people are migrating more towards warmer climates. This can also affect their access to food because not many elderly people drive, or family members are not around to help them access proper food resources.

Behavioral change has a big impact on food insecurity because of the choices individuals make when it comes to nutritional choices. For example, food consumption plays a role in behavioral choices because one can chose how much to eat in one setting.

When individuals are hungry late at night or just want something quick and cheap, they are more likely to access a fast food place rather than selecting fresh fruits and vegetables. Controlling food intake is important through education. If people are more aware and understand fats, oils, sugars and carbohydrates they are more likely to make healthier nutritional choices. Another important educational practice could be learning how to read the back of a nutritional label while grocery shopping to decide which food belongs in the cart. Although, this can be hard to do when there is a transformation of food systems. This shift can be seen in both grocery stores and in the environment where fast food chains are rapidly growing. More processed foods are being sold in grocery stores because they are affordable and easy to make. However, people are not aware of the amount of sodium, antibiotics, and other nutritional resources that are in processed foods.

\section{Food Security in Slovakia}

According to the foodsecurityindex. eiu, (2017), Slovakia is ranked $34^{\text {th }}$ out of 70 countries in Europe for food security. Throughout numerous research articles, Slovakia is a country that has improved food security compared to neighboring countries. Three strengths Slovakia has to approach this issue is presence of food safety net programs, nutritional standards, and food safety. Slovakia also ranks 32 in the category of affordability. This indicator considers the food safety net programs which include in-kind food transfers; conditional cash transfers (food vouchers); the existence of school feeding programs funded by the government (foodsecurityindex.eiu, 2017). The data also indicated the presence of food safety net programs is $1.4 \%$ above the world average in this category.

One of the challenges that was found while conducting this research was protein quality. According to foodindexsecurity. eiu, (2017), Slovakia is $-13.8 \%$ below the world average in protein quality. Protein is an essential part of a diet because it is an important building block of bones, muscles, skin, and blood. It also helps in building and repairing tissue.

\section{Conclusion}

Research and innovation are two drivers that will help increase food security in Europe and globally. Focusing on nutrition and diet are key. Food insecurity does not only 
present an issue in Europe, but worldwide. It is a social problem, which leads to a public health problem because without the proper nutrients, chronic diseases and other significant health problems can arise. Education, implementation, and change are key drivers to help turn people from food insecure to secure and living an active healthy life.

\section{References}

1. DZURICKOVA J (2014) The Food Security in Conditions of the Slovak Republic. msed. vse.cz. Retrieved, October 2, 2018.

2. ESAC (2017) Opportunities and challenges for research on food and nutrition security and agriculture in Europe. European Academics Science Research Health. Retrieved, September $20^{\text {th }}, 2018$. From http://www.Easac.eu.

3. EUROPEAN COMMISSION |CHOOSE YOUR LANGUAGE | CHOISIR UNE LANGUE | WÄHLEN SIE EINE PRACHE (2018) Food and nutrition security - European Commission. Retrieved August 20,
2018, from http://ec.europa.eu/europeaid/ sectors/food-and-agriculture/food-and-nutrition-security_en.

4. EUROPEAN COMMISSION (2018) Food and Nutrition Security. Retrieved October 2, 2018. Fromhttp://ec.europa.eu.

5. EUFIC (2018) Time to recognize malnutrition in Europe. Retrieved October 5, 2018. From http://www.eufic.org.

6. KULASIKOVA M, COLLAKOVA M (2018) Leg support, Rehabilitation, 2018, Vol. 55, No. 1, ISSN0375-0922, p. 19 - 30.

7. MANTIVANI M P (2017) Food Insecurity and Children's Rights to Adequate Nutrition in Europe. European Pediatric Association. Retrieved October 4, 2018. From https:www.ipeds.com/article/S0223476(18)30596-1/pdf.

8. THE ECONOMIST INTELLIGENCE UNIT (2014) Food security in focus: Europe 2014 on http://foodsecurityindex.eiu. com; FAO regional office for Europe (with a main focus on the Caucasus) on www.fao. org/3/a-i4649e.pdf. 